\title{
Miscanthus harvesting technologies and computer-assisted cost estimation of biomass production
}

\author{
Dariusz Kwaśniewski ${ }^{1, *}$ \\ ${ }^{1}$ Faculty of Production and Energy Engineering, University of Agriculture in Krakow, Balicka 116B, \\ 30-149 Krakow, Poland
}

\begin{abstract}
The purpose of the paper was to determine the costs of production of biomass from Miscanthus, for various harvesting technologies. The study includes harvest in the form of chaff and compacted straw, on a 10 ha plantation. The scope of work includes estimated calculations for six different variants, computed with the application "BiOBkalkulator". The biomass production costs were very diverse and ranged from PLN 80 $\cdot \mathrm{t}^{-1}$ (PLN 1613.ha ${ }^{-1}$ ) for the small-scale streamlined harvesting technology, to PLN $258 \cdot \mathrm{t}^{-1}\left(\mathrm{PLN} 5,158 \cdot \mathrm{ha}^{-1}\right)$ for the self-propelled forage harvesting technology, using own machinery (IVa). The costs of harvesting and transporting Miscanthus constitute from approx. 41 to over $80 \%$ of the biomass production costs, depending on the variant used.
\end{abstract}

\section{Introduction}

The basic groups of energy plants are:

- annual plants (cereals, rape, corn, sugar cane, sorghum),

- short-rotation woody crops (willow, poplar, aspen),

- perennial, fast-growing grasses (reed canary grass, Miscanthus),

- perennial, fast-growing herbs (Pennsylvanian mallow, Jerusalem artichoke) $[1,2]$.

The grasses of the genus Miscanthus, family Paniculate, originated in warm Asian areas. In Japan, the grasses have been used e.g. for feed production and roofing for thousands of years. In the 1930s, due to their appeal, shape and inflorescences, they were brought to Europe as decorative plants [3]. The plant is also known as silvergrass, elephant grass or Chinese silver grass[4].

The harvest of perennial plants (grasses and herbs) can be carried out with rotary mowers or forage harvesters (tractor- or self-propelled). Forage harvesters, especially those with Kemper or Krone row-indepent units, are most often used nowadays. These plants can also be harvested annually with corn harvesters. After being cut with rotary, low-powered

\footnotetext{
* Corresponding author: kwasniewski.darek@gmail.com
} 
mowers, and raking into swaths, the plants can be harvested with large round, or rectangular balers $[5,6]$.

Miscanthus can be harvested in late autumn (November-December) with forage harvesters, but biomass with $35-55 \%$ humidity is obtained (depending on the genotype and year), which is of little use for transport and storage. Shifting the harvest of Miscanthus to early spring allows obtaining biomass with a moisture content of $20-30 \%$, and using the equipment used for harvesting hay or straw for the purpose. Miscanthus biomass with a moisture content of approx. $20 \%$ can be pressed, which facilitates transport and storage. In spring, however, a smaller yield is obtained, of approx. 25\% [7].

The cost of production of biomass for energy purposes is determined by the amount and the price of the yield, the field area and harvesting technology. The cost per unit mass decreases as the crop increases. Also, the use of modern, high-performance machines, working in the fields of a larger acreage, allows to significantly reduce costs [6]. The selection and operation of machinery $[8,9]$ used in biomass production processes also plays a very important role.

In the production processes of biomass from perennial energy crops, the following stages can be distinguished: establishing a plantation, using (running) it, and its liquidation. The biomass production costs are associated with these stages, and the planned lifetime of the plantation is an important factor that should be taken into account in the cost estimation. Costs related to plantation establishment and liquidation per years of use will allow estimation of average annual costs of plantation maintenance [10,11].

The cost of harvesting biomass from perennial energy crops (including Miscanthus) plays an important role in the overall production costs, which are directly related to the harvesting technology used.

\section{Aim, scope and methodology of work}

The purpose of the paper was to determine the costs of production of biomass from Miscanthus, taking into consideration the cost of harvesting and transport. The scope of work covers theoretical (estimated) calculations for various harvest technologies (variants), whereas the biomass production costs were computed using the "BiOBkalkulator".

Miscanthus harvesting technologies taken into consideration:

- Technology I - harvesting with a mower and small-size press

- Variant Ia - manual harvest (manual loading/unloading of bales)

- Variant Ib - streamlined harvest (conveyor behind the press and manual unloading)

- Technology II - harvesting with a mower and a round baler

- Technology III - harvest with a tractor-propelled forage harvester, streamlined collection, transport with the use of two trailers with extensions (used interchangeably),

- Technology IV - harvest with a self-propelled forage harvester, streamlined collection, transport with the use of two trailers with extensions (used interchangeably),

- Variant IVa - own forage harvester

- Variant IVb - forage harvester as a service.

In the study, the following calculation assumptions were made:

- Miscanthus cultivation area: 10 ha,

- fresh biomass yield: $20 \mathrm{t} \cdot \mathrm{ha}^{-1}$.

- dry biomass yield: $12 \mathrm{t} \cdot \mathrm{ha}^{-1}$.

- plantation lifetime: 18 years, 
- distance between plantation and place of biomass storage: $10 \mathrm{~km}$,

- transporting vehicle speed: $15 \mathrm{~km} \cdot \mathrm{h}^{-1}$.

- operator fee: PLN $13 \cdot$ man-hour $^{-1}$.

- helper fee: PLN $10 \cdot$ man-hour $^{-1}$.

- fuel price: PLN $5.10 \cdot 1^{-1}$.

- unit cost of the self-propelled forage harvester service: PLN $800 \cdot \mathrm{h}^{-1}$.

- estimated costs of establishing a Miscanthus plantation: $16975 \mathrm{PLN} \cdot \mathrm{ha}^{-1}$.

The costs of biomass production from Miscanthus were estimated using the "BiOBkalkulator" application. It was created by employees of the Faculty of Production and Power Engineering at the University of Agriculture in Krakow, as part of the Commissioned Research Project No. PBZ-MNiSW - 1/3/2006 titled: "Modern technologies for the energy use of biomass and biodegradable waste $/ \mathrm{BiOB} /$ - conversion of $\mathrm{BiOB}$ to energy gas fuels".

The application is available at: http://biob.wipie.ur.krakow.pl/biobkalk/ [12].

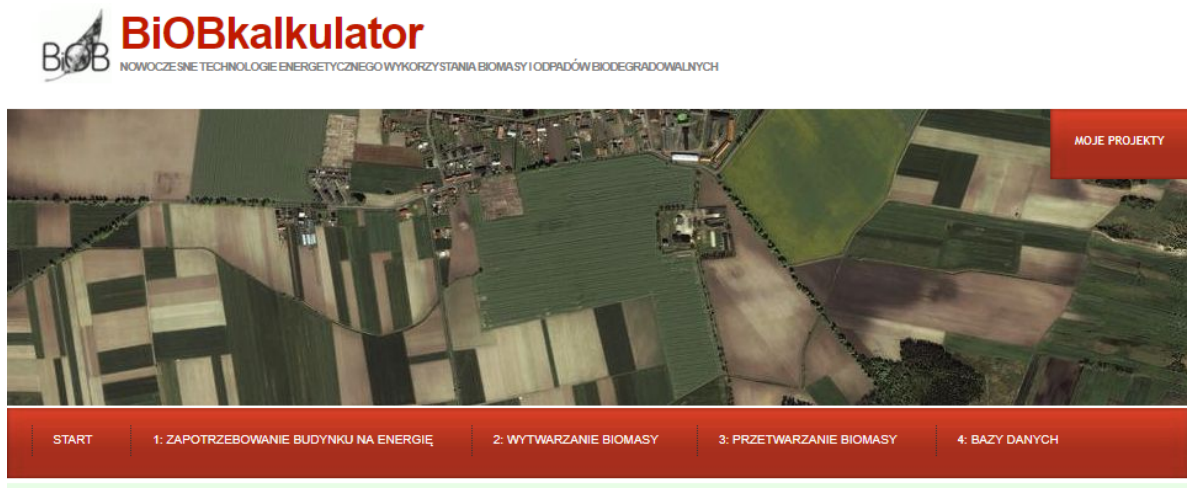

\section{Zawartość Witaj w aplikacji BiOBkalkulator}

$\begin{array}{ll}\text { Opprojekcie } & \text { BiOBkalkulator jest informatycznym systemem kompleksowego doradztwa w zakresie produkcji i przetwarzania } \\ \text { Aplikacja BioBkalkulator } & \begin{array}{l}\text { biomasy jako substytutu konwencjonalnych nośników energii wykorzystywanych do celów grzewczych. Ma on } \\ \text { charakter modułowy, tj. wyodrębniono cztery oddzielne moduly, z których użytkownik może korzystać } \\ \text { niezależnie lub w polaczeniu z pozostalymi modułami. }\end{array}\end{array}$

Fig. 1. The "BiOBkalkulator" home page.

"BiOBkalkulator" is an IT system for comprehensive consulting in the field of production and processing of biomass, as a substitute for conventional energy sources used for heating. It is modular, i.e. It offers four separate modules, which the user can use independently, or in combination with the others.

- Module 1: allows estimating the energy demand for heating a building (conventional energy sources or biomass), and perform an estimated energy audit of the building.

- Module 2: allows estimating labor and energy expenditure on the production of biomass from field crops, as well as the biomass production costs and calorific value of the biomass.

- Module 3: allows estimating labor and energy expenditure, as well as the production costs of compact biofuels (briquettes or pellets) from biomass.

- Module 4: offers a database of machinery for the production, processing and combustion of biomass. 
In this work, module 2 was used to calculate the costs of production of Miscanthus biomass. The costs were determined as the sum of plantation depreciation costs (a quotient of plantation establishment costs and its planned period of use), and the costs of biomass harvesting in the following year, taking into account various harvesting technologies.

Mechanization costs associated with the collection and transport of Miscanthus biomass were determined in accordance with the methodology used at the Institute of Agricultural Engineering and Computer Science of the University of Agriculture in Krakow $[11,13]$. Technical and operational parameters of the machine park used for harvesting and transporting Miscanthus biomass were adopted based on data and standards from the literature $[14,15]$.

Below is an example of calculating the cost of Miscanthus biomass production using the "BiOBkalkulator".

Figure 2 shows the user's first step: entering input parameters for the selected plant (in this case, Miscanthus). Based on values such as the cultivation area and the assumed crop, as well as by adjusting the biomass humidity, the amount of energy contained in the dry matter is automatically calculated.

\begin{tabular}{|c|c|c|}
\hline Powierzchnia uprawy & ha & 10.0 \\
\hline Zakladany plon świeżej masy & t/ha & 20.0000 \\
\hline Wilgotność & $\%$ & 40.0000 \\
\hline Plon suchej masy & t/ha & 12.0000 \\
\hline \multicolumn{3}{|l|}{ Obliczenia } \\
\hline Wartosć opalowa & $\begin{array}{l}\mathrm{kWh} / \mathrm{kg} \\
\mathrm{N} / \mathrm{kg}\end{array}$ & $\begin{array}{l}2.5622 \\
9.2240\end{array}$ \\
\hline $\begin{array}{l}\text { llośc energii z jednostkowej powierzchni } \\
\text { uprawy }\end{array}$ & $\begin{array}{l}\mathrm{kWh} / \mathrm{ha} \\
\mathrm{GJ} / \mathrm{ha}\end{array}$ & $\begin{array}{l}51244.4444 \\
184.4800\end{array}$ \\
\hline Ilosć energï w jednostkowej masie plonu & $\begin{array}{l}\mathrm{kWh} / \mathrm{t} \\
\mathrm{GJ} / \mathrm{t}\end{array}$ & $\begin{array}{l}2562.2222 \\
9.2240\end{array}$ \\
\hline Ilość energii calkowita & $\begin{array}{l}\text { kWh } \\
\text { GJ }\end{array}$ & $\begin{array}{l}512444.4444 \\
1844.8000\end{array}$ \\
\hline
\end{tabular}

Fig. 2. Input parameters for calculations

The next step involves the selection of energy and labor expenditure and costs for establishing the plantation. The application's authors included a table (Fig. 3), which presents suggested numerical ranges and specific values for three different field acreage (1, 5 and $10 \mathrm{ha}$ ). The ultimate combination of parameters depends on the user. At this stage, it is also possible to assume plantation lifetime, which is necessary to calculate plantation depreciation. 


\begin{tabular}{l|c|r|r|r|r|r}
\multirow{2}{*}{ Wyszczególnienie } & \multirow{2}{*}{ Jednostka } & \multicolumn{2}{c|}{ Przedziat } & \multicolumn{3}{|c}{ Plantacje } \\
\cline { 3 - 8 } & & \multicolumn{1}{c}{ min } & \multicolumn{1}{c}{ max } & 1 ha & 5 ha & 10 ha \\
\hline Naktady pracy & {$[\mathrm{rbh} / \mathrm{ha}]$} & 79 & 780 & 358 & 344 & 140 \\
\hline Naktady energetyczne & {$[\mathrm{kWh} / \mathrm{ha}]$} & 472 & 1240 & 667 & 1064 & 1172 \\
\hline Koszty mechanizacji & {$[\mathrm{zt} / \mathrm{ha}]$} & 2177 & 7640 & 4855 & 3655 & 3385 \\
\hline Koszty materiatowe & {$[\mathrm{zt} / \mathrm{ha}]$} & 13270 & 15740 & 15740 & 14650 & 13590 \\
\hline Koszty założenia plantacji & {$[\mathrm{zt} / \mathrm{ha}]$} & 16530 & 20980 & 20595 & 18305 & 16975
\end{tabular}

Wprowadź w poniższym formularzu szacunkowe wartości kosztów, nakładów energetycznych i nakładów pracy założenia plantacji.

Koszty
\begin{tabular}{|l|l|l|}
\hline Szacunkowy koszt założenia plantacji & $\mathrm{zt} / \mathrm{ha}$ & 16975.0 \\
\hline Szacunkowe nakłady energetyczne & $\mathrm{kWh} / \mathrm{ha}$ & 1172.0 \\
\hline Szacunkowe nakłady pracy & rbh/ha & 140.0 \\
\hline Okres użytkowania plantacji & lata & 18.0 \\
\hline
\end{tabular}

Fig. 3. Estimation of costs, energy and labor expenditure in establishing a plantation

Expenses and costs associated with establishing the plantation include spring field preparation, purchase and planting of seeds, as well as some care treatments performed during the first months of the plantation's operation, which are necessary for the proper development of Miscanthus.

The next step in calculating production costs using the "BiOBkalkulator" is to choose the harvesting technology (Fig. 4). For Miscanthus, the available harvesting variants are: pressed form (cubes or bales) and chaff.

The application allows not only to select tractors and machines, but also to edit and change their parameters (e.g. fuel price, capacity, actual annual use, etc.) as well as the parameters of the entire unit (e.g. the number of operators, trailers, etc.). After entering the data, the costs of processing are determined, as well as the labor and energy expenditure incurred for harvesting and transport.

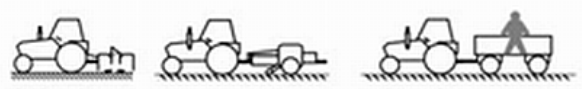

Zbiór slomy zageszczonej prasa malogabarytowa. Koszenie kosiarka rotacyjna lub dyskowa. Prasowanie Transport. Zaladunek i rozladunek reczny,Szczególy

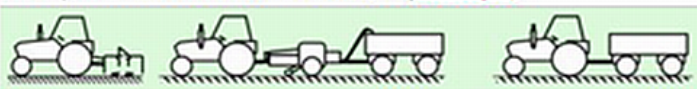

Zbiór slomy zageszczonej prasa malogabarytowa. Koszenie kosiarka rotacyjna lub dyskowa. Prasowanie bezpośrednim zaladunkiem (przyczepy stosowane zamiennie - zbiór potokowy). Rozladunek reczny \$zczesóly

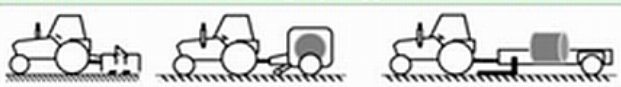

Zbiór slomy zagęszczonej prasą zwijająa - baloty duże. Koszenie kosiarką rotacyjna lub dyskowa. Prasowaniє Transport zbieraczem bel Szczególy

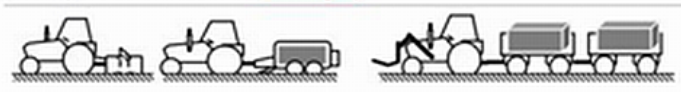

Zbiór slomy zagęszczonej - baloty duże prostopadlościenne. Koszenie kosiarka rotacyjna lub dyskowo Prasowanie. Transport platformami - zaladunek i rozladunek ladowaczen czolowym Szczególy

Fig. 4. Selection of harvesting technology 
After determining the cost of harvest, the application also allows estimating the cost of transport. Similarly to earlier stages, the user can select machines and their parameters to match their needs. At this point, the distance from the field to the biomass storage place, and the transport speed, should also be estimated.

For the purpose of this paper, tractors for both harvesting and transport were selected in such a way to enable a sound comparison of individual technologies. In many cases, the basic criterion, i.e. the unit's power requirement, has been extended to include the need to match the same tractor to several variants.

Wykorzystane w zabiegu zbioru maszyny
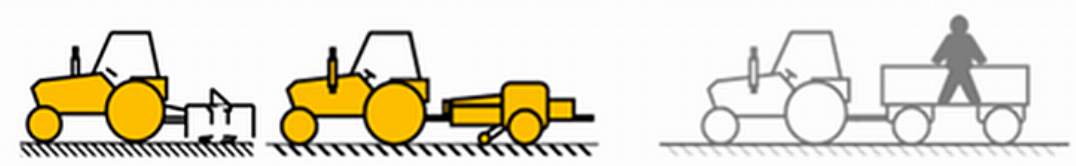

\begin{tabular}{|c|c|}
\hline $\begin{array}{l}\text { Ciagnik (agregat do scinania): } \\
\text { Ciøgnik rolniczy U4512 }\end{array}$ & Wymien I Edytui \\
\hline $\begin{array}{l}\text { Kosiarka: } \\
\text { Kosiarka rotacyjna zawieszona ze spulchniaczem Z125/2K (FMR } \\
\text { Famarol S.A. Stupsk) }\end{array}$ & Wymien I Edytuj \\
\hline $\begin{array}{l}\text { Ciagnik (agregat do prasowania): } \\
\text { Ciegnik rolniczy U3512 }\end{array}$ & Wymien I Edytui \\
\hline $\begin{array}{l}\text { Prasa zbierajaca - baloty male: } \\
\text { Prosa zbierojaca } 2224 / 1\end{array}$ & Wymieñ I Edvtui \\
\hline
\end{tabular}

Zmien inne parametry agregatu

Fig. 5. Selection of machines and their parameters used for harvesting in technology Ia Wyniki

\begin{tabular}{|l|r|r|}
\hline Koszt wykonania zabiegów koszenia i prasowania & $z t$ & 4918.766 \\
\hline Koszt wykonania zabiegów koszenia i prasowania & $z$ tha & 491.877 \\
\hline Koszt wykonania zabiegów koszenia i prasowania & $z \mathrm{t} / \mathrm{t}$ & 24.594 \\
\hline Naklady pracy (koszenie + prasowanie) & $\mathrm{rbh} / \mathrm{ha}$ & 2.650 \\
\hline Naklady pracy (koszenie + prasowanie) & $\mathrm{rbh} / \mathrm{t}$ & 0.132 \\
\hline Naktady energetyczne (koszenie + prasowanie) & $\mathrm{kWh} / \mathrm{ha}$ & 74.983 \\
\hline Naklady energetyczne (koszenie + prasowanie) & $\mathrm{kWh} / \mathrm{t}$ & 3.749 \\
\hline
\end{tabular}

Fig. 6. Results for harvest using technology Ia 
Wykorzystane w zabiegu transportu maszyny

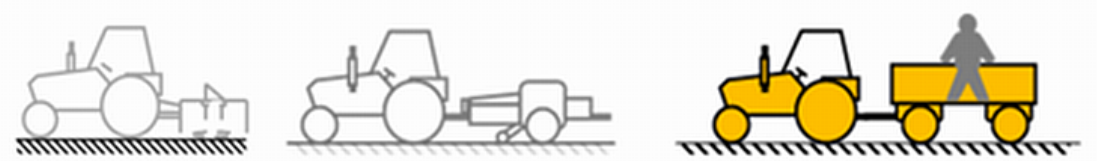

Ciagnik (agregat transportowy):

Ciqgnik rolniczy U4512

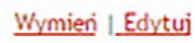

Przyczepa:

Przyczepa rolnicza 0732

Wymien I Edytuj

Zmien inne parametry arrezatu

Fig. 7. Selection of machines and their parameters used for transport in technology Ia Wyniki

\begin{tabular}{|l|r|r|}
\hline Koszt wykonania zabiegu & $z t$ & 8176.379 \\
\hline Koszt wykonania zabiegu & $z \mathrm{t} / \mathrm{ha}$ & 817.638 \\
\hline Koszt wykonania zabiegu & $\mathrm{zt} / \mathrm{t}$ & 40.882 \\
\hline Naklady pracy & $\mathrm{rbh} / \mathrm{ha}$ & 25.000 \\
\hline Naklady pracy & $\mathrm{rbh} / \mathrm{t}$ & 1.250 \\
\hline Naklady energetyczne & $\mathrm{kWh} / \mathrm{ha}$ & 202.083 \\
\hline Naklady energetyczne & $\mathrm{kWh} / \mathrm{t}$ & 10.104 \\
\hline
\end{tabular}

Fig. 8. Results for transport using technology Ia

The last stage of calculations is the collective result of biomass production costs, i.e. establishing a plantation, of harvesting and transport, as well as final results, in which production costs are calculated per hectare and tonne of biomass. In addition, the cost of generating energy is also estimated, in PLN $\cdot \mathrm{kWh}^{-1}$.

\section{Findings:}

The cost of harvesting and transporting biomass from energy crops is one of the components of biomass production costs. The unit cost of harvesting and transporting Miscanthus biomass, as well as production costs calculated per ton of fresh weight, are shown in Figure 9. 


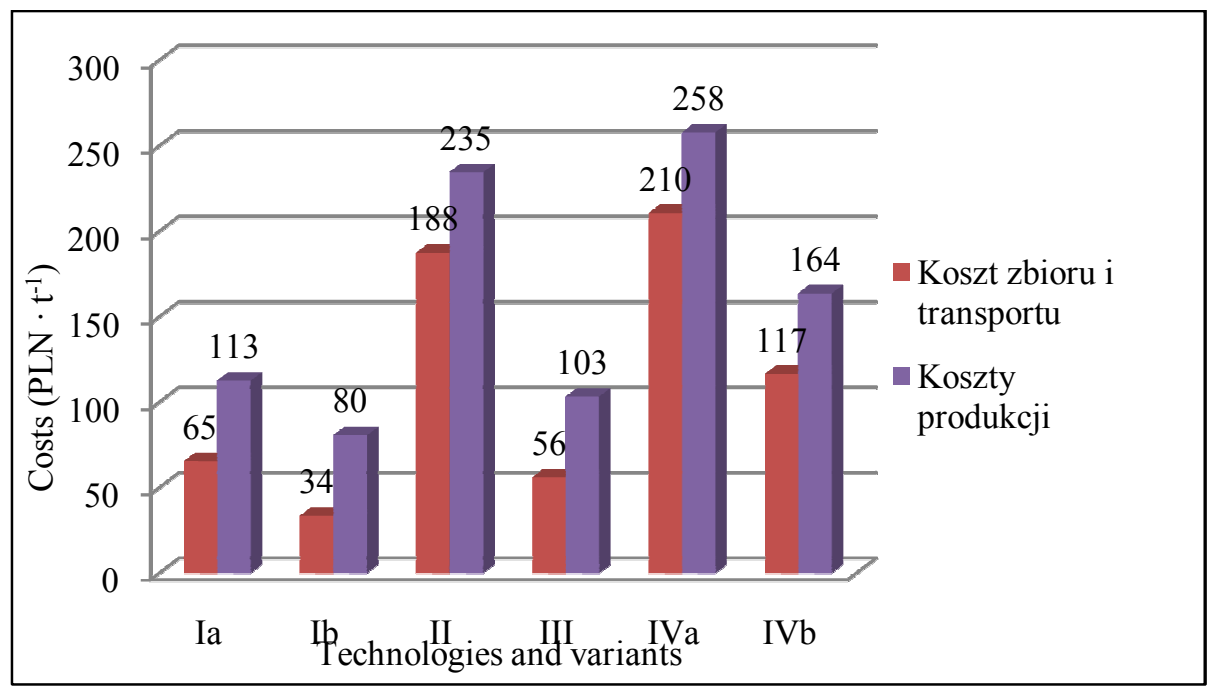

Fig. 9. Comparison of the costs of Miscanthus biomass harvest and transport with the total costs of its production

The lowest production costs (PLN $\left.80 \cdot \mathrm{t}^{-1}\right)$ was noted for technology I (variant Ib), i.e. harvesting straw in a pressed form of small rectangular bales loaded from the press onto a trailer using a conveyor. However, the highest costs were characteristic for technology IV (variant IVa), in which a self-propelled forage harvester purchased for own use was used. In this scenario, the financial expenditure incurred for the production of biomass is PLN $258 \cdot \mathrm{t}^{-1}$. For the other variants, the production costs are as follows: for technology Ia - PLN $113 \cdot \mathrm{t}^{-1}$, for technology II $-235 \mathrm{PLN} \cdot \mathrm{t}^{-1}$, for technology III $-103 \mathrm{PLN} \cdot \mathrm{t}^{-1}$, and for technology IVb - PLN $164 \cdot \mathrm{t}^{-1}$.

The differences between the costs incurred for harvesting and transport in individual technologies are similar to the differences between the costs of biomass production and constitute from approx. 41 to over $80 \%$, depending on the variant used.

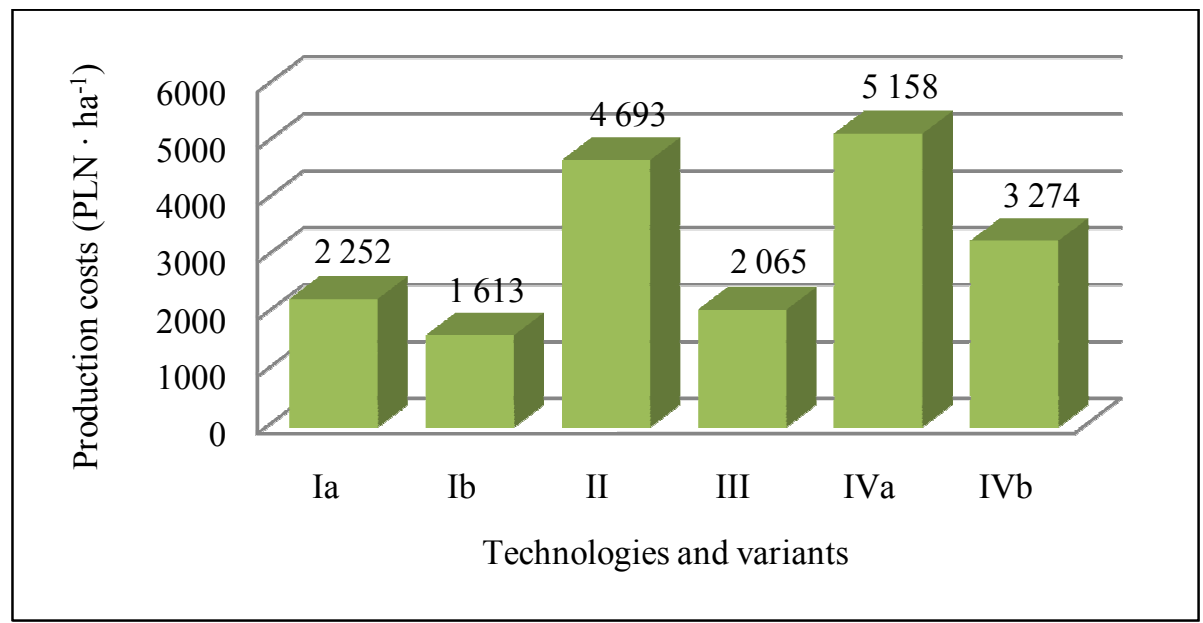

Fig. 10. Miscanthus biomass production costs in PLN $\cdot h a^{-1}$ 
The estimated costs incurred per hectare of plantation (similarly to ton of biomass above) are the lowest with technology I (variant Ib), at PLN $1613 \cdot \mathrm{ha}^{-1}$, and the highest for technology IV (option IVa), at PLN 5,158 $\mathrm{ha}^{-1}$. In addition, comparatively high values (PLN $4693 \cdot \mathrm{ha}^{-1}$ ) were noted in the two-stage harvest using a mower and a round baler (technology II). In the case of using a round baler, the obtained biomass is formed in cylindrical bales of considerable unladen weight, which precludes manual loading and unloading. For this purpose, a tractor equipped with a bale gripper must be used to place the bales on the trailer and transport them, or use a so-called bale collector that combines the function of loading and transporting compressed straw from the field to the place of storage. Since this type of machine can carry a maximum of 8 bales in one journey, and the transport distance was 10 kilometers, the cost of transport proved to be very high. This increased the harvesting costs, and thus the cost of production. The obtained results indicate that the variant using own, self-propelled forage harvester yields the worst financial result (variant IVa) due to the very high cost of purchase of the machine, as well as the limited time of its use during the year. The purchase price of the forage harvester adopted in this study is nearly PLN 1.5 million, which results in several times higher operating costs, as compared to other machines used. Moreover, considering that its annual use is only 100 hours, applying this type of technology on a plantation of 10 ha is unprofitable at such high costs.

From the energy viewpoint, the most important indicator of the usefulness of an energy source is its price related to the amount of energy it provides. Presenting production costs in the above way allows comparing the Miscanthus biomass not only with the other shortrotation plants, but also with other renewable and conventional energy sources. Therefore, Figure 11 presents the production costs per unit of energy $\left(\mathrm{PLN} \cdot \mathrm{kWh}^{-1}\right)$.

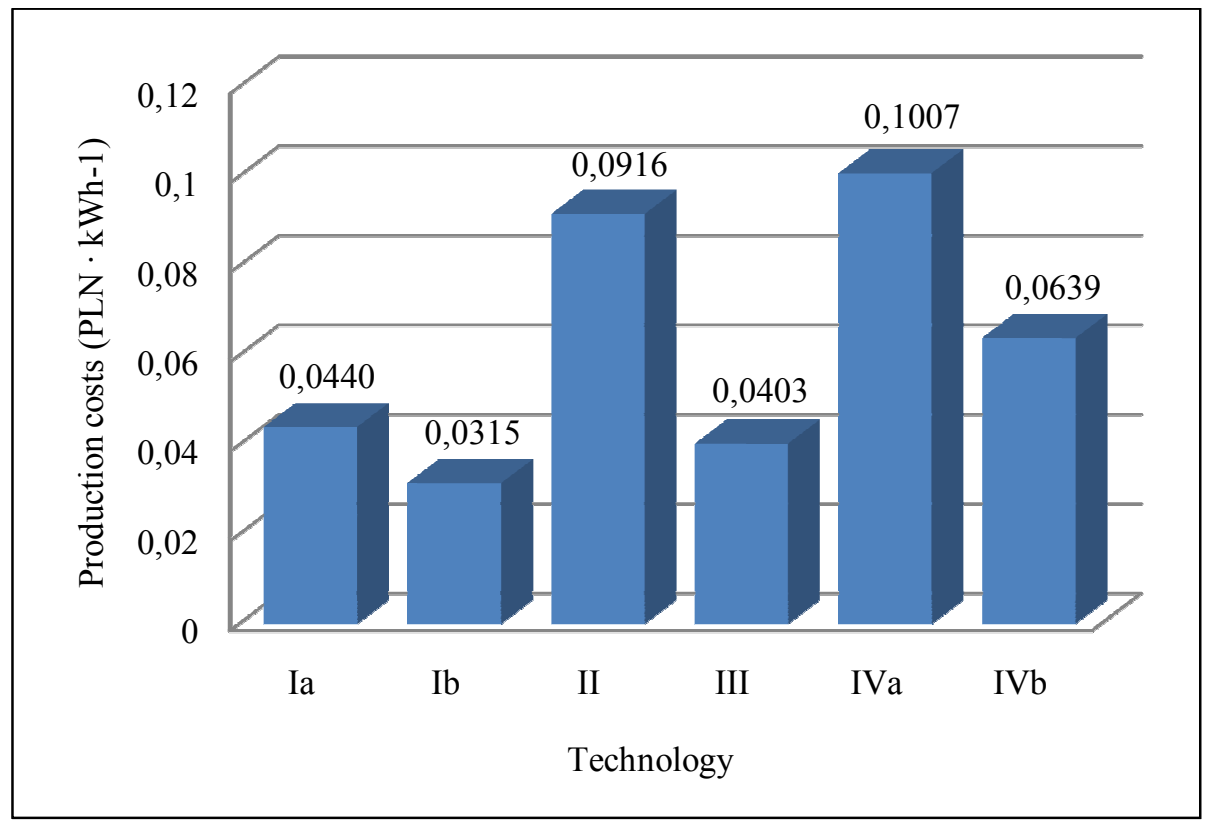

Fig. 11. Miscanthus biomass production costs in $\mathrm{PLN} \cdot \mathrm{kWh}^{-1}$ 
In the above calculations, the costs incurred to produce $1 \mathrm{kWh}$ of energy range from PLN $0.0315 \cdot \mathrm{kWh}^{-1}$ for the small-scale streamlined harvesting technology (Ib), to PLN $0.1007 \cdot \mathrm{kWh}^{-1}$ for the technology using a self-propelled forage harvester purchased for own use (IVa).

\section{Conclusions}

1. Following the input data, the "Biokalkulator" allows estimating the costs of biomass production from energy crops, including Miscanthus.

2. Result analysis demonstrated that for the harvesting technologies specified in the work, the costs of transport and harvesting range from PLN 33.5 $\cdot \mathrm{t}^{-1}$ (PLN 670.4 $\cdot \mathrm{ha}^{-1}$ ) for technology I (variant Ib), to PLN $210.8 \cdot \mathrm{t}^{-1}\left(4,215.3 \mathrm{PLN} \cdot \mathrm{ha}^{-1}\right)$ for technology IV (option IVa). The costs constitute from approx. 41 to over $80 \%$ of the biomass production costs, depending on the variant used.

3. The lowest production cost was noted for technology I (variant Ib), i.e. harvesting straw in a pressed form of small rectangular bales loaded from the press onto a trailer using a conveyor. They amount to just over PLN $80 \cdot \mathrm{t}^{-1}$. However, the highest costs were characteristic for technology IV (variant IVa), in which a self-propelled forage harvester purchased for own use was used (258 PLN $\left.\cdot{ }^{-1}\right)$.

4. Estimated costs of biomass production from Miscanthus, calculated per plantation area, are the lowest with technology Ib, at PLN $1613 \cdot \mathrm{ha}^{-1}$. In turn, the highest cost is characteristic for the technology IVa, amounting to PLN 5,158 $\cdot \mathrm{ha}^{-1}$. In addition, compared to other variants, technology II stands out with high production costs (PLN $\left.4693 \cdot \mathrm{ha}^{-1}\right)$.

5. In the above calculations, the costs incurred to produce $1 \mathrm{kWh}$ of energy range from PLN $0.0315 \cdot \mathrm{kWh}^{-1}$ for the small-scale streamlined harvesting technology (Ib), to PLN $0.1007 \cdot \mathrm{kWh}^{-1}$ for the technology using a self-propelled forage harvester purchased for own use (IVa).

\section{Literature}

1. R.S. Pacaldo, T.A. Volk ,Briggs R., Bioenergy Research 6, 252-262. (2012).

2. A. Kacprzak, K. Michalska, R Z. Romanowska-Duda, M. Grzesik, Kosmos Problemy Nauk Biologicznych. Polskie Towarzystwo im. Kopernika, 61, 282. (2012)

3. S. Szczukowski, J. Tworkowski, M. Stolarski, J. Kwiatkowski, M. Krzyżaniak, W. Lejszner, Ł. Graban, Monografia. Multico Oficyna Wydawnicza sp. z o.o. (2012).

4. J. Kuś, M. Matyka. Instrukcja upowszechnieniowa nr 179. IUNG-PIB. Puławy. 24-25. (2010)

5. A. Lisowski (ed.), Wyd. SGGW. Warsaw. ISBN 978-83-7583-222-8. (2010).

6. K. Ericsson, H. Rosenqvist, E. Ganko, M. Pisarek, L. Nilsson, Biomass and Bioenergy 30 5, 16-27. (2006)

7. S. Szczukowski, J. Tworkowski, J. Kuś, M. Stolarski, Nowoczesne technologie pozyskiwania i energetycznego wykorzystania biomasy. Bocian, Golec, Rakowski (ed.). Instytut Energetyki, Warsaw, 34-49. (2010).

8. M. Cupial, A. Szelag-Sikora, M. Niemiec, In: Huyghebaert, B., Lorencowicz, E. and Uziak, J. (eds.), Farm Machinery and Processes Management in Sustainable Agriculture, 64-69. (2015).

9. Z. Kowalczyk, M. Cupiał, Contemporary Research Trends in Agricultural Engineering BIO Web Conf., 10 (2018). 
10. D. Kwaśniewski, W: Frączek J. (ed.) Produkcja biomasy na cele energetyczne. Wyd. DRUKROL S.C., Krakow, 149-165, (2010)

11. D. Kwaśniewski, Inżynieria Rolnicza 1 126, 145-154, (2011).

12. http://biob.wipie.ur.krakow.pl/biobkalk/.

13. J. Kowalski, R. Michałek, M. Kuboń, D. Kwaśniewski, U. Malaga-Toboła, S. Tabor, Uwarunkowania techniczno-ekonomiczne produkcji ekologicznej w gospodarstwach Polski potudniowej, (2014).

14. A. Muzalewski. A., Koszty eksploatacji maszyn. Wyd. IBMER Warsaw, (2009).

15. Lorencowicz E., Poradnik uzytkowania techniki rolniczej w tabelach, Agencja Promocji Rolnictwa i Agrobiznesu, Bydgoszcz, (2007). 